\title{
Assessing the sustainability status of mangrove forest ecosystem management by coastal community in Jaring Halus Village, North Sumatra, Indonesia
}

\author{
EDY SAHPUTRA $^{1, \boldsymbol{v}}$, R. HAMDANI HARAHAP ${ }^{2}$, HESTI WAHYUNINGSIH ${ }^{3}$, BUDI UTOMO ${ }^{4}$ \\ ${ }^{1}$ Doctoral Program of Natural Resources and Environmental Management, School of Graduate, Universitas Sumatera Utara. Jl. Dr. T. Mansur No. 9 , \\ Medan 20155, North Sumatra, Indonesia. Tel.: +62-61-8212453, "email: mayor.sahputra@ gmail.com \\ ${ }^{2}$ Department of Anthropology, Faculty of Social and Political Sciences, Universitas Sumatera Utara. Jl. Dr. A. Sofian No.1 A, Medan 20155, North \\ Sumatra, Indonesia \\ ${ }^{3}$ Department of Biology, Faculty of Mathematics and Natural Sciences, Universitas Sumatera Utara. Jl. Bioteknologi No. 1, Medan 20155, North \\ Sumatra, Indonesia \\ ${ }^{4}$ Department of Forestry, Faculty of Forestry, Universitas Sumatera Utara. Jl. Tri Darma Ujung No. 1, Medan 20155, North Sumatra, Indonesia
}

Manuscript received: 13 December 2020. Revision accepted: 4 December 2021.

\begin{abstract}
Sahputra E, Harahap RH, Wahyuningsih H, Utomo B. 2021. Assessing the sustainability status of mangrove forest ecosystem management by coastal community in Jaring Halus Village, North Sumatra, Indonesia. Biodiversitas 22: 1-9. Mangrove forest ecosystems provide various important ecological (physical and protection) and economic services. Mangrove forest needs to be sustainably managed to ensure their functions and benefits are available in perpetuity. Still, issues regarding sustainable management of mangrove forests are rarely discussed, especially in Indonesia. This research aims: (i) to gain the fundamental understanding of the level of sustainable mangrove management by determining indicator attributes that can be categorized as leverage factors; ii) obtain the perceptions of coastal communities in mangrove forest management; and iii) investigate the compliance of coastal communities in mangrove forest management. Data were obtained through a series of interviews, field observation and focused group discussion (FGD) and questionnaires conducted from January 2018 to March 2019 in Jaring Halus Village, Secanggang Subdistrict, Langkat District, North Sumatra, Indonesia. Data were analyzed using multidimensional scaling (MDS). The results showed that the status of mangrove forest management in Jaring Halus Village was categorized as moderately sustainable with a score of $65.83 \%$. The majority of the coastal community (96\% of respondents) perceived and understood the value of protecting the mangrove ecosystem, which provided physical (ecological), economic, and social functions. The community's understanding and knowledge of the importance of mangrove forests is due to the high level of dependency on their main livelihood as fishermen. Around 97\% of the respondents held strong obedience to the mangrove forest management in Jaring Halus Village, which could be attributed to local wisdom related to natural resource management.
\end{abstract}

Keywords: Jaring Halus Village, leverage pattern, local wisdom, mangrove forest, sustainability

\section{INTRODUCTION}

Indonesia and four other countries, namely Australia, Brazil, Nigeria and Mexico, cover $48 \%$ of the world's mangrove forests (Van Lavieren 2012). Until the end of 2000 , Indonesia's mangrove forest area was estimated to be $3,112,989$ ha or $22.6 \%$ of the total mangrove area in the world (Giri et al. 2011). Based on One Map Mangrove data, the area of the mangrove ecosystem in Indonesia is 3.5 million ha, consisting of 2.2 million ha under state forest areas (Kawasan Hutan) and 1.3 million ha outside the state forest. Apart from its vast area, mangroves in Indonesia are also known to harbor a high species diversity which remains a possibility for finding undocumented species (Hutchison et al. 2014; Joshi and Ghose 2014; Nfotabong-Atheull et al. 2011; Zhang et al. 2007). It is recorded that there are at least 202 mangrove species in Indonesia, 43 of which (consisting of 33 tree species and several shrubs) are classified as true mangrove species, while the rest are associated mangroves (Snedaker 1984).

Mangrove forests are an important biological resource for the coastal areas of Indonesia. They possess a variety of biological functions, including food resources (Alimbon and Manseguiao 2021), nesting sites, breeding grounds and habitats for various marine organisms, such as fish and shrimp, and other wildlife species. Furthermore, mangrove ecosystems have ecological services in terms of protecting coastlines, regulating sedimentation, improving water quality and controlling seawater intrusion, storing carbon and stabilizing micro-climate, and providing economic resources such as timber and non-timber products (honey, tannins) and ecotourism (Askornkoae and Kato 2011; Giri et al. 2015; Kathiresan and Bingham 2001; Kusmana 2014; Spalding et al. 2010)

However, several mangrove ecosystems in certain areas have been experiencing extensive deforestation and habitat conversion in recent days (Kusmana 2014). This circumstance creates various problems since mangrove forests are a transitional ecosystem in almost all coastal areas in the Indonesian archipelago, from Sumatra, Java, Kalimantan, Bali, Sulawesi, Maluku, and Papua (Kusmana et al. 2003; Marbawa et al. 2014; Muhtadi et al. 2016; 
Prasetyo et al. 2014; Rugayah 2007; Setiawan et al. 2017; Wouthuyzen and Ahmad 2018). Ecologically, mangrove deforestation will pose negative threats and subsequent impacts on both abiotic and biotic components in the mangrove area, e.g. seawater intrusion, decreased land quality, decreased quality and quantity of groundwater. Pendleton et al. (2012) added that mangrove deforestation might lead to an increased concentration of greenhouse gases (GHG) in the atmosphere, affecting climate change.

One of the damaged mangrove forests in North Sumatra is the Karang Gading Wildlife Reserve, located in the northeastern part of Langkat District. After the 1990s, there has been a lot of pressure on the Wildlife Reserve in which the surrounding areas have been converted into the human settlement as happened in Jaring Halus Village (BBKSDA Sumatera Utara 2019). Jaring Halus Village is located adjacent to the Karang Gading Wildlife Reserve and is at the estuary between two large rivers which are strategic and unique. Jaring Halus Village has a land area of 83 ha in of which 18 ha is mangrove forest. Apart from the conversion into the settlement, the substantial impact on the decline in the ecological function of mangroves in Jaring Halus was observed due to the expansion of concession area (i.e. logging, oil palm, and aquaculture concessions) in the production forest of the Northeast Langkat region. This business entity has expanded in several areas of the Wildlife Reserve, including the area of the Jaring Halus community (BBKSDA Sumatera Utara 2009).

Mangrove deforestation in the area has greatly impacted the economy of the Jaring Halus community, especially regarding fish catching activities in which the volume is declining afterward. In addition to the expansion of concession areas, the rate of deforestation is further increased by the establishment of charcoal refineries that heavily rely on mangrove timbers as raw materials. Illegal logging in mangrove forest areas also occurs in some fairly dense mangrove forests. This problem has been suppressed temporarily by shutting down the charcoal refinery in the vicinity of the Wildlife Reserve area. Therefore, this research aimed to study the level of sustainable mangrove ecosystem management in Jaring Halus Village by determining attribute indicators (leverage factors). We also investigated any local wisdom integrated into the forest resource management while determining local perception related to preserving mangrove areas in the villages. Moreover, the compliance of coastal communities in mangrove forest management was also investigated to reveal the role of observed local wisdom in mangrove management.

\section{MATERIALS AND METHODS}

\section{Study period and area}

This research was conducted from January 2018 to March 2019 in Jaring Halus Village, Secanggang Subdistrict, Langkat District, North Sumatra (Figure 1). The coordinate of the village was $3^{\circ} 51^{\prime} 30^{\prime} \mathrm{N}-3^{\circ} 59^{\prime} 45^{\prime} \mathrm{N}$ and $98^{\circ} 30^{\prime} \mathrm{E}-$ $98^{\circ} 42^{\prime} \mathrm{E}$. The altitude of the studied location was $\pm 1 \mathrm{mdpl}$. The area had a month's rainfall of 1 month and daily temperature reaching $28^{\circ} \mathrm{C}$. The population of the coastal community of Jaring Halus Village was 1,880 people, consisting of 99 fishermen, 1,096 fishery business workers, and 685 fishery business owners (BPS Langkat, 2017).

\section{Procedures}

Primary data was collected by combining the methods of Focus Group Discussion (FGD), in-depth interviews with experts, and questionnaires. The determination of sample size which resulted in 330 respondents in this study was based on Slovin's formula as follows:

$$
\begin{aligned}
& n=\frac{N}{1+N e^{2}} \\
& \text { Where: } \\
& n \quad=\text { sample size } \\
& N \quad=\text { population size } \\
& e \quad=5 \% \text { error level }
\end{aligned}
$$

The respondents consisted of Head of Village, Head of Regional Planning and Development Agency (Bappeda) of Langkat District, Department of Fisheries and Agriculture of Langkat District, Environmental Division Head, Hygiene and Gardening Division of Langkat District, Agency for Natural Resources Conservation (Balai Besar Konservasi Sumber Daya - BBKSDA) of North Sumatra Province, and coastal communities of Jaring Halus Village (i.e., fishermen, boat and fisheries workers, business owners and key respondents). Primary data were directly obtained from key respondents through Focus Group Discussions (FGD).

The information and knowledge from experts were conducted through in-depth interviews. The expert survey followed the RAPFISH procedure with the purpose of setting indicators and providing scores on each sustainability indicator. The tool used was the Rap-Mangrove forest technique as a modified approach from the RAPFISH (Rapid Appraisal for Fisheries). Secondary data were obtained from documentation studies and research results, related literature studies, and monograph data of research locations. The tool used is the Rap-Mangrove forest technique as a modified approach from the RAPFISH (Rapid Appraisal for Fisheries) program developed by the Fisheries Center, University of British Columbia.

\section{Data analysis}

The assessment of the sustainability status of mangrove forest ecosystem management in Jaring Halus Village was carried out using the Multi-Dimensional Scaling (MDS) technique. MDS is a statistical analysis technique that attempts to carry out multidimensional transformations into simpler dimensions (Kavanagh and Pitcher 2004). RapMangrove forest modification was carried out on the dimensions and attributes in the analysis, in accordance with the research objectives. MDS was used to assess the sustainability status index and identify the most sensitive attributes of each sustainability dimension (from the ecological, economic and social dimensions) through leverage analysis. The evaluation of the sustainability of mangrove forest ecosystem management using the MDS method is carried out through several stages: 

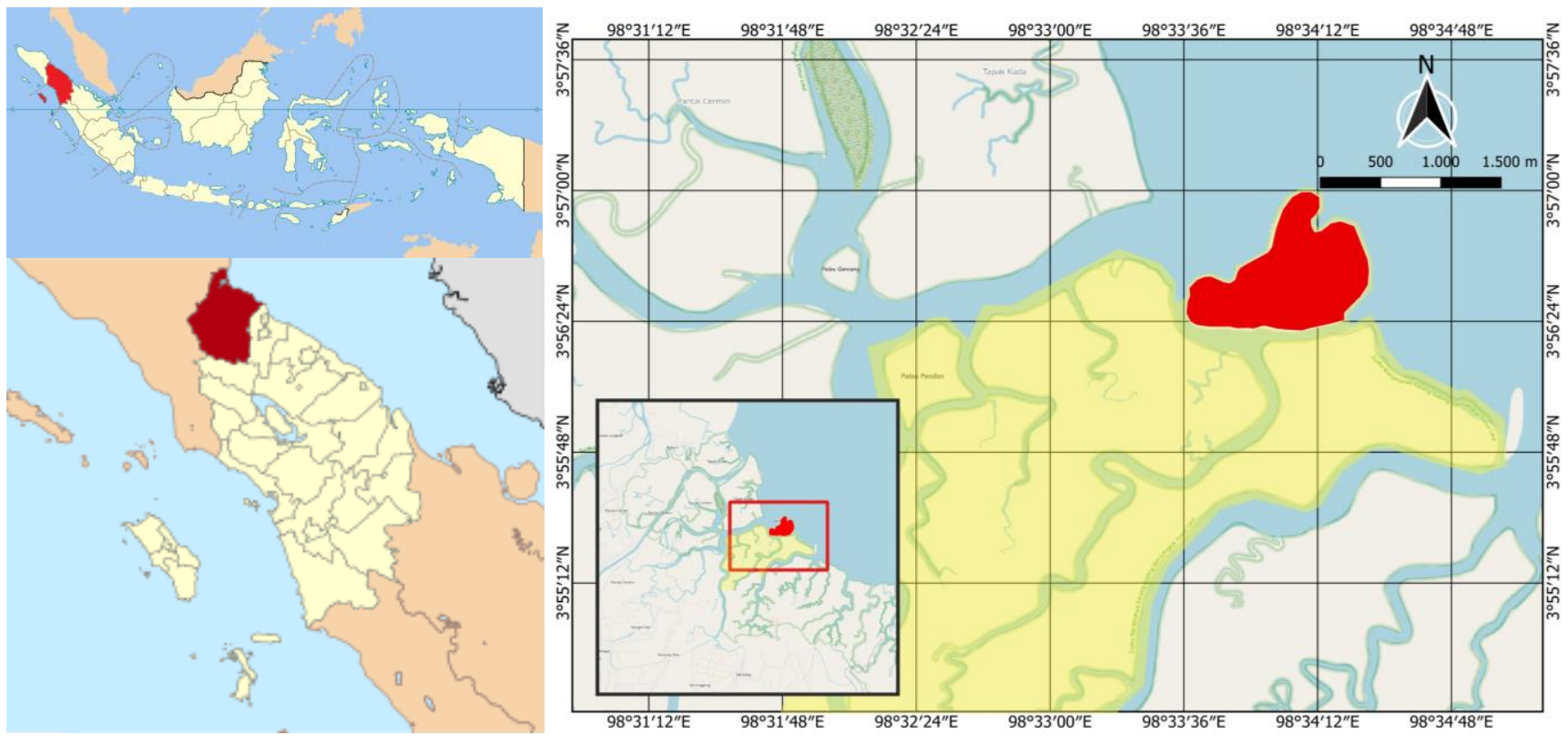

Figure 1. A. Map of Indonesia with Sumatra Island marked by a red box, B. Map of study area showing the location of Jaring Halus Village (Red Box), Langkat District, North Sumatra Province, Indonesia

The determination of management attributes of sustainable mangrove forest ecosystems for each dimension. (i) In this study, four dimensions of sustainable development were used: ecological, economic, social, and cultural dimensions. (ii) The evaluation of each attribute on an ordinal scale (scoring) based on the sustainability criteria of each dimension. The appraisal of the attributes was carried out using questionnaires with information from several respondents to determine the scores of each attribute from each dimension. The assessment is based on an ordinal scale that reflects bad and good values, where the range of scores depends on the state of each attribute. Bad values reflect the most unfavorable conditions for the sustainability of mangrove ecosystem management, while good values reflect the most favorable conditions in supporting the management of sustainable mangrove ecosystems in Jaring Halus Village. There are one or more intermediate values between these two extreme values, depending on the number of ranks for each attribute. (iii) Analysis of Rap-Mangrove forest ordination with the MDS method to determine the position of the sustainability status in each dimension on the sustainability index scale. (iv) Assessing the index and sustainability status in each dimension. The sustainability index value of each dimension can be visualized in the form of a kite diagram. Symmetrical kite diagrams are determined by the sustainability index of each dimension (ecological, economic, and social). This sustainability index value is analyzed multi-dimensionally to determine the point that reflects the position of the sustainability of mangrove ecosystem management relative to the reference point, both good and bad. The sustainability status category of the mangrove ecosystem management in Jaring Halus Village based on the index value of Rap-Mangrove forest analysis results is presented in Table 1. (v) Conducting a sensitivity analysis (Leverage analysis) to determine which sensitive variables affect sustainability. Sensitive variables are attributes that have leverage factors and contribute to the sustainability index of the mangrove forest management in Jaring Halus Village. The determination of sustainable management leverage attributes of mangrove forest ecosystems is based on the "root mean square" (RMS) value. The RMS value indicates the importance of the role of each attribute towards the sensitivity of the sustainability index (Kavanagh and Pitcher 2004). The greater the value of the RMS changes due to the loss of a certain attribute, the greater the role of these attributes in the formation of a sustainability index value on the scale of sustainability is. (vi) The Monte Carlo analysis was performed to take into account the dimensions of uncertainty (Kavanagh and Pitcher 2004). This analysis observes and evaluates the effect of errors by assessing ordination. The effect of errors can be caused by various conditions, such as mistakes in calculating scores due to the imperfect understanding of attributes or field conditions, variations in scores due to differences in opinion or judgment of researchers, repetitive MDS analysis processes, errors in data entry or missing data, iterative stability, and high-stress values (stress values are acceptable if the value is $<25 \%$ ) (Pitcher and Preikshot 2001). The goodness of fit on MDS is reflected in the number of S-stress values calculated based on the values of $\mathrm{S}$ and $\mathrm{R}^{2}$. A lower stress value indicates a condition of suitability and a high $\mathrm{S}$ value indicates the opposite. Through the Rap-Mangrove forest approach, a good model can be obtained from stress values that are smaller or less. 
Table 1. Category of the sustainable status based on the index value analysis using Rap-Mangrove forest method

\begin{tabular}{ll}
\hline Index value $(\%)$ & Category \\
\hline $0.00-25.00$ & Unsustainable \\
$25.01-50.00$ & Less Sustainable \\
$50.01-75.00$ & Moderate Sustainable \\
$75.01-100.00$ & Sustainable \\
\hline Source $\cdot$ Kavanagh and Pitcher $(2004)$
\end{tabular}

Source: Kavanagh and Pitcher (2004)

\section{RESULTS AND DISCUSSION}

\section{Score of dimensions of sustainable mangrove forest management}

Assessment of the management sustainability of mangrove forest ecosystem in Jaring Halus Village included three dimensions, namely ecological, economic and social. Each dimension consists of several attributes. Based on the extraction results, a total of twenty-four attributes were obtained for all the dimensions as presented in Table 2.

\section{Sustainability status}

Mangrove forest ecosystem management requires an integrated approach that accommodates the interests of various sectors and stakeholders. Therefore, three dimensions of sustainability (ecological, economic, and social) on the management of mangrove ecosystem in Jaring Halus Village were incorporated with the results of the index value assessment can be seen in Table 3.

The results showed that the average index value on the mangrove forest management in Jaring Halus Village was classified as moderately sustainable with a score of $65.83 \%$. The analysis results for each sustainability dimension showed that the economic, social, and ecological dimensions had a fairly sustainable status. The ecological dimension had the highest value, meaning that it is sustainable. Each dimension must remain sustainable in the future. Therefore sensitive attributes in each dimension need to be validated by different interventions. Based on the ecological attributes in Table 2, there are three attributes that become leverage factors because of their sensitivity in changing the sustainability value, namely: availability of seeds for rehabilitation, types of land use, and the critical level of mangrove forests.

Based on the field observations in the customary forest in Jaring Halus Village, we recorded 15 mangrove species consisting of three growth levels, namely trees, poles and sapling (Table 4). At the tree stage, 14 mangrove species were found with 1,596 individuals, 14 mangrove species at the pole stage with 1,350 individuals, and 15 mangrove species at the sapling stage with 1,534 individuals.

In Table 4, it can be seen that 15 species of mangrove were found in the studied area, comprising four families of true mangroves, namely Avicenniaceae, Rhizophoraceae, Rhizophoraceae, and Sonneratiaceae, while the others were from associated mangroves including Acanthaceae, Euphorbiaceae. Combretaceae, Arecaceae and Meliaceae. Acanthus ilicifolius, or in local name jeruju, was documented at two levels of growth, namely pole (110 ind.) and sapling (232 ind.). A. ilicifolius was recorded in two sampled sites, namely river estuaries where people used to fish and near community settlements. According to Agoramoorth et al. (2008), besides being used for ornamental and medicinal plants, A. ilicifolius can also be used as a bioindicator of pollution in the forest area and ponds. Furthermore, Ardli et al. (2011) state that A. ilicifolius was commonly monitored to assess the quantitative environmental quality.

Table 3. The index value of sustainability status of mangrove forest management in Jaring Halus Village, Langkat District, North Sumatra Province, Indonesia

\begin{tabular}{lc}
\hline Dimension & Index value $(\boldsymbol{\%})$ \\
\hline Ecology & 72.50 \\
Economy & 69.72 \\
Social & 55.27 \\
MDS average & 65.83 \\
\hline
\end{tabular}

Tabel 2. Dimensions and attributes of the sustainability of mangrove forest ecosystem management in Jaring Halus Village, Langkat District, North Sumatra Province, Indonesia

\begin{tabular}{|c|c|c|}
\hline Dimension & Attributes & Total \\
\hline Ecology & $\begin{array}{l}\text { Type of land use, crown density, soil resistance to abrasion, changes in water quality, food chains and } \\
\text { ecosystems, effort to preserve mangrove forest ecosystems, availability of seeds for rehabilitation, and } \\
\text { critical/degradation level of mangrove forest }\end{array}$ & 8 \\
\hline Economy & $\begin{array}{l}\text { The average income of the community, availability of funds for mangrove forest rehabilitation, number of } \\
\text { businesses created and coordinated, improvement of alternative livelihoods, percentage of the population } \\
\text { living below the poverty line, utilization of mangroves by the community, employment and income from } \\
\text { mangrove tourism. }\end{array}$ & 8 \\
\hline Social & $\begin{array}{l}\text { Understanding of the environment, community knowledge about mangrove forests, community participation in } \\
\text { mangrove forest management, work ethic, facilitation and community assistance in the management of } \\
\text { mangrove forest ecosystems, strengthening and enhancing the participation of local communities in } \\
\text { management activities, conflict of the utilization of mangrove resources and local wisdom. }\end{array}$ & 8 \\
\hline
\end{tabular}


Table 4. Species richness and population structure of mangrove forest in Jaring Halus Village, Langkat District, North Sumatra, Indonesia

\begin{tabular}{|c|c|c|c|c|}
\hline \multirow{2}{*}{ Species } & \multirow{2}{*}{ Family } & \multicolumn{3}{|c|}{ Number of individual(s) } \\
\hline & & Tree & Pole & Sapling \\
\hline Acanthus ilicifolius & Acanthaceae & 0 & 110 & 232 \\
\hline Avicennia alba & Avicenniaceae & 190 & 113 & 113 \\
\hline Avicennia marina & Avicenniaceae & 228 & 43 & 20 \\
\hline Bruguiera sexangula & Rhizophoraceae & 56 & 67 & 67 \\
\hline Excoecaria agallocha & Euphorbiaceae & 134 & 140 & 112 \\
\hline Lumnitzera racemosa & Combretaceae & 120 & 0 & 130 \\
\hline Nypa fruticans & Arecaceae & 90 & 33 & 33 \\
\hline Rhizophora apiculata & Rhizophoraceae & 153 & 130 & 203 \\
\hline Rhizophora mucronata & Rhizophoraceae & 109 & 156 & 198 \\
\hline Rhizophora stylosa & Rhizophoraceae & 145 & 121 & 150 \\
\hline Xylocarpus granatum & Meliaceae & 76 & 105 & 150 \\
\hline Sonneratia caseolaris & Sonneratiaceae & 172 & 142 & 142 \\
\hline Sonneratia alba & Sonneratiaceae & 65 & 10 & 42 \\
\hline Ceriops decandra & Rhizophoraceae & 23 & 120 & 33 \\
\hline Ceriops tagal & Rhizophoraceae & 35 & 60 & 61 \\
\hline Total & & 1,596 & 1,350 & 1,534 \\
\hline
\end{tabular}

The main causes of deforestation of mangrove forests in Southeast Asia are land conversion to agriculture and oil palm plantations, development of shrimp ponds, and community settlements (Giri et al. 2015; Richards and Friess 2016, Thomas et al. 2017). The exploitation of mangrove forests through Forest Concession Rights or Hak Pengusahaan Hutan (HPH) private companies may result in a monopoly on forest exploitation which is the major contributor to deforestation in the Karang Gading Wildlife Reserve and may have an impact on the customary forest of Jaring Halus Village. According to Djufri (2015), the practice of HPH did not provide additional benefit to the local community living around the forest, but instead facilitated further deforestation. The decline in the carrying capacity of the forest will pose a serious threat, especially within the buffer zone of the wildlife reserve.

Disturbed mangrove forest ecosystems due to habitat conversion will eliminate the ecological, economic and social functions of the forest (Polidoro et al. 2010; Valiela et al. 2001). Mangrove land rehabilitation may positively impact the environment, which in turn improves the local community welfare (Sudtongkong and Webb 2008, Janmaimool 2016). Based on the leverage analysis of economic attributes in Table 2, there were three sensitive attributes in the management of mangrove forest ecosystems in Jaring Halus Village, such as increasing or improving alternative livelihoods (diversification of business owned by the community), the percentage of the population living under poverty, and the utilization of mangroves by the community. Alteration in these attributes will simply affect the index value of the sustainable economic dimension. The alternative livelihood or business diversification developed by the Jaring Halus community is listed in Table 5.

Improvement of alternative livelihoods or business diversification had a close relationship with the welfare of the coastal communities of Jaring Halus Village which served as an additional income to the fishermen if they did not go fishing. The minimum wage in Medan City (the capital of North Sumatra) in 2019 was 3,222,556 IDR, while the distribution of the income level of fishermen per month in Jaring Halus Village was in a low category with an average income between 600,001 to $1,500,000$ IDR or $67.88 \%$ less than the minimum wage. Based on Table 5, it can be seen that the majority of business diversification owned by coastal communities in Jaring Halus Village was the fish processing into food products $(51.57 \%)$, followed by other minor businesses $(34.37 \%)$ and fishery businesses $(14.06 \%)$. Through the business diversification, it is hoped that the level of community welfare will also increase, from low and middle-level groups to high-income groups. Based on data from BPS (2018), the high-income group is defined as the average income between 2,500,000 and 3,500,000 IDR per month.

Based on the leverage analysis from the social dimensions in Table 2, there were two attributes that most sensitive and influence the management of mangrove forest ecosystems, namely: work ethic and understanding of the environment. Changes in these two factors will easily affect the social dimension index value of the sustainability index value. The coastal community of Jaring Halus Village had a community group called IPANJAR. IPANJAR community groups worked together with the community in mangrove nurseries and planting. IPANJAR also conducted monitoring of village forests voluntarily together with the community. According to BBKSDA Sumatera Utara (2019), the capacity-building activities by the IPANJAR group were often managed by involving Agency for Social Forestry and Environmental Partnership (Balai Perhutanan Sosial dan Kemitraan Lingkungan-BPSKL) and District Services for Cooperatives, Small and Medium Enterprise (Dinas Koperasi Kecil dan Menengah). IPANJAR community groups and Jaring Halus Village communities collaborated with related agencies, NGOs and university academics in biodiversity management. Collaborative activities that were routinely carried out included inventory and identification of aquatic mammals (dolphins), captive breeding and monitoring of horseshoe crabs, mangrove restoration, and certified seed propagation activities (e.g. Rhizophora stylosa and Rhizophora apiculata). 
Table 5. Business diversification by coastal community in Jaring Halus Village, Langkat District, North Sumatra, Indonesia

\begin{tabular}{lcc}
\hline Business type(s) & n & $\begin{array}{c}\text { Percentage } \\
(\%)\end{array}$ \\
\hline Fishery business (floating fish cages) & 55 & 14.06 \\
$\begin{array}{l}\text { Fish processing into food products (salted } \\
\text { fish, fish chips, fermented fish paste) }\end{array}$ & 185 & 51.57 \\
$\begin{array}{l}\text { Other minor businesses (grocery store, } \\
\text { fresh fish, restaurant) }\end{array}$ & 85 & 34.37 \\
Total & 330 & 100 \\
\hline
\end{tabular}

\section{Local wisdom of Jaring Halus community related to mangrove forest management}

The mangrove forest in Jaring Halus Village had an estimated extent of 18 ha. The mangrove forest, which consisted of 15 mangrove species, was managed very well through customary regulations agreed upon by the communities. In general, the people have understood the importance of the mangrove ecosystem for the survival of the community both physically, ecologically and economically. The community's understanding and knowledge of the importance of mangrove forests was due to the high level of dependence related to the main livelihood of the community as fishermen. The expected results were in concordance to the statements by Bengen (2000; 2001; 2004), Setiawan et al. (2017), and Prasetyo et al. (2014) who stated that mangrove forest is one of the tropical natural resources which has a broad spectrum of functionalities and benefits in terms of ecological and economic aspects. The ecological function of mangroves can be seen from the physical, chemical and biological elements.

The mangrove forest in Jaring Halus Village may be regarded as a successful example that showed the sole management by its local community and must be emulated by the Government of Indonesia. It may seem practical and strategic to adopt the local wisdom in natural resources management by the Jaring Halus community, especially to manage the damaged habitat of Karang Gading Wildlife Reserve which is located adjacent to the Jaring Halus Village. Jaring Halus Village has a unique tradition, and its people are known to be friendly and open to foreigners. The unique tradition practiced by the coastal community of Jaring Halus Village is the jamu laut. The tradition is a ritual to honor the ancestors who managed the oceanic region and are believed to provide welfare for fishermen and people living on the coastline. This is a cultural heritage that has been going on for centuries, although its recent implementation has been adjusted to the religion adopted in each region regarding its practical matters. The goal of the ritual is to provide the safety and welfare of coastal communities. The jamu laut ritual is held every three years, depending on the sea diviner. According to Aida and Zuska (2017), the jamu laut ritual aimed to forge and strengthen kinship among village communities.
In the context of realizing the management of natural resources, as expected the community strives to impose customary values related to natural resource management, especially village forests which are formulated in an agreement. Some of the rules regarding village forests that are known and bind the community to comply, among others, can be seen in Table 6 .

\section{Community perception of mangrove forest management}

The community perception of mangrove forest management was based on questionnaires distributed to 330 respondents. The majority of the respondents (96\%) were understood and familiar with the mangrove ecosystem, its functions, benefits, and ways of managing mangrove forests as presented in Table 7.

\section{Conformity of Jaring Halus community related to mangrove forest management}

The majority of the respondents $(97 \%)$ had great conformity with the mangrove forest management with the details as presented in Table 8 .

\section{Management of mangrove forest in Jaring Halus Village}

Efforts for the sustainable management of mangrove forests in Jaring Halus Village have been documented in several ways. The local community cultivated mangrove species based on existing potential. On 1 December 2019, the village head, village officials and the community planted mangrove seedlings including Avicennia spp. (apiapi), Sonneratia spp. (pedada), Bruguiera spp., Rhizophora spp. (bakau), Nypa fructicans (nipah), Xylocarpus granatum, and Excoecaria agallocha as many as 5000 seeds. Planting was performed to utilize the coastal area.

The establishment of customary protected sites in the mangrove forest area of Jaring Halus Village has been initiated indigenously while being promoted by the government as one of the Traditional Villages and National Ecosystem Areas. The local community maintained local wisdom by preserving customs or rituals and maintaining the marine ecosystem as their source of life which is the superiority of the Jaring Halus community. The potential of natural resources that are well maintained and conserved with the customs system is the basis of it.

Based on the interviews with pawang (diviners) and respondents, it was known that several customary or sacred rules in the utilization of timber obtained from the mangrove forest in Jaring Halus Village were documented as presented in Table 6 . These findings suggest the importance of increasing participation and empowerment in preserving mangrove forests. Efforts to protect the mangrove forest were not carried out by particular officers but on a voluntary basis. It was also known that there was awareness from the community to replant degraded mangrove sites by planting mangrove fruits or propagules. 
Table 6. Local wisdom practiced by the Jaring Halus community, Langkat District, North Sumatra, Indonesia

\begin{tabular}{ll}
\hline $\begin{array}{l}\text { Cultural } \\
\text { approach(es) }\end{array}$ & Type of local wisdom \\
\hline Notion & $\begin{array}{l}\text { It is not justified to harvest mangrove timber for commercial purposes } \\
\text { It is not allowed to damage the mangrove forest due to the presence of ancestors } \\
\text { Mangrove forest provides livelihoods for the community } \\
\text { It is not allowed to dispose of anything in the sacred sites } \\
\text { It is not allowed to harvest mangrove timber for building structures, weddings or traditional events without the } \\
\text { permission of the diviner and the village head }\end{array}$ \\
& $\begin{array}{l}\text { Twigs and logs may be utilized for firewood and other purposes } \\
\text { Timber may be harvested for fishing equipment, house poles, hall, and firewood for weddings or funerals }\end{array}$ \\
& $\begin{array}{l}\text { Mangrove forest is a zone for women to seek marine products and is prohibited for men by custom. } \\
\text { Norm(s)/ }\end{array}$ \\
In the tradition of jamu laut, offerings (eg., goat's head, chicken's head and cow's head), are left at the shore, as a \\
symbol for the blessings of the sea. \\
A day of abstinence is a day where for 24 hours people are not allowed to remove any water from the land or the sea \\
A day of abstinence is also a day for not cutting timber in 40 days \\
As additional gratitude to the sea, there is a customary on fish harvesting based on a specific size \\
The food that is brought into sacred sites must be disposed to ensure the safety of journey and its destination \\
People who damage the marine ecosystem will be imposed by customary fines. \\
Naw & No.ere is no current law on mangrove forest and fish resources management \\
\hline
\end{tabular}

Table 7. Community perception on mangrove forest management in Jaring Halus Village, Langkat District, North Sumatra, Indonesia

\begin{tabular}{|c|c|c|c|}
\hline Indicator(s) & $\begin{array}{l}\text { Respondents } \\
\text { (Ind.) }\end{array}$ & $\begin{array}{l}\text { Percentage } \\
(\%)\end{array}$ & Perception \\
\hline $\begin{array}{l}\text { Knowledge of mangrove } \\
\text { ecosystem }\end{array}$ & 330 & 100 & $\begin{array}{l}\text { Majority of respondents understand very well that mangrove forests are } \\
\text { forest areas that are influenced by saline water, consisting of mangroves } \\
\text { (Avicennia or api-api) and other species as well as being a habitat for various } \\
\text { species of animals, birds, fish and shellfish. }\end{array}$ \\
\hline $\begin{array}{l}\text { Function and benefit of } \\
\text { mangrove forest }\end{array}$ & 330 & 100 & $\begin{array}{l}\text { Majority of respondents understand the functions and benefits of mangrove } \\
\text { forests as a physical barrier from erosion, high tides, and as a place to find } \\
\text { fish, crabs, clams, firewood and building materials. }\end{array}$ \\
\hline $\begin{array}{l}\text { Effect of mangrove forest on } \\
\text { catch or fishery products }\end{array}$ & 320 & 96 & $\begin{array}{l}\text { Majority of respondents understand very well that the presence of mangrove } \\
\text { forests affects their catch or fishing results. }\end{array}$ \\
\hline $\begin{array}{l}\text { Deforestation and illegal } \\
\text { fishing }\end{array}$ & 319 & 96 & $\begin{array}{l}\text { Majority of respondents understand fairly regarding mangrove deforestation } \\
\text { and illegal fishing, which may lead to the decrease or even of fish resources. }\end{array}$ \\
\hline $\begin{array}{l}\text { Dependence on economic } \\
\text { activity and community } \\
\text { livelihood }\end{array}$ & 280 & 96 & $\begin{array}{l}\text { Majority of respondents are very highly dependent on mangrove forest } \\
\text { resources due to their main fishing activities and business diversification }\end{array}$ \\
\hline $\begin{array}{l}\text { Benefit of mangrove forest } \\
\text { conservation }\end{array}$ & 330 & 84 & $\begin{array}{l}\text { Majority of respondents understand well that the conservation of mangrove } \\
\text { forest provides benefits to the community in both economical and physical } \\
\text { contributions }\end{array}$ \\
\hline $\begin{array}{l}\text { Efforts in mangrove forest } \\
\text { management }\end{array}$ & 330 & 100 & $\begin{array}{l}\text { The community agrees that the efforts to conserve mangrove forests in Jaring } \\
\text { Halus Village are quite high }\end{array}$ \\
\hline Conclusion & $\begin{array}{l}\text { The underst } \\
\text { regarding th }\end{array}$ & $\begin{array}{l}\text { g or perce } \\
\text { ainable s }\end{array}$ & $\begin{array}{l}\text { tion of the local community in Jaring Halus Village is quite resourceful } \\
\text { tus and efforts of mangrove forest management }\end{array}$ \\
\hline
\end{tabular}

Table 8. Conformity of the local community on mangrove forest management in Jaring Halus Village, Langkat District, North Sumatra, Indonesia

\begin{tabular}{|c|c|c|c|}
\hline Indicator(s) & Respondent(s) & $\begin{array}{l}\text { Percentage } \\
(\%)\end{array}$ & Perception \\
\hline $\begin{array}{l}\text { Awareness upon mangrove forest } \\
\text { conservation }\end{array}$ & 312 & 94 & The awareness level of the community is still considered low \\
\hline $\begin{array}{l}\text { Existence of rules, norms, prohibitions, } \\
\text { taboo, and local wisdom in mangrove } \\
\text { forest conservation }\end{array}$ & 330 & 100 & $\begin{array}{l}\text { The community acknowledge any rules, norms, prohibitions, } \\
\text { taboo, and local wisdom created for the mangrove forest } \\
\text { conservation }\end{array}$ \\
\hline $\begin{array}{l}\text { Community consent if the rules, norms, } \\
\text { customs, values of local wisdom are } \\
\text { made in written rules or laws }\end{array}$ & 330 & 100 & $\begin{array}{l}\text { The community consent to make rules, norms, customs, local } \\
\text { wisdom values into written rules (legal formal) is very high }\end{array}$ \\
\hline $\begin{array}{l}\text { Sanctions and sentences for scofflaws in } \\
\text { the mangrove forest }\end{array}$ & 320 & 96 & $\begin{array}{l}\text { The community strongly agree to the implementation of } \\
\text { sanctions and sentences according to the rules }\end{array}$ \\
\hline $\begin{array}{l}\text { Participation of the community in the } \\
\text { mangrove forest management }\end{array}$ & 310 & 93 & $\begin{array}{l}\text { The participation of the community in mangrove forest } \\
\text { management is considered high and fairly enthusiastic }\end{array}$ \\
\hline Conclusion & \multicolumn{3}{|c|}{$\begin{array}{l}\text { The conformity of the local community in Jaring Halus Village is quite good regarding the } \\
\text { conservation efforts in mangrove forest management }\end{array}$} \\
\hline
\end{tabular}


There have been many outreach activities about the threats caused by mangrove deforestation both from academics who conducted independent community service and research as well as from NGOs and the Langkat District Forestry Service. In addition, the coastal community of Jaring Halus Village has contributed to the conservation efforts, especially regarding the sustainability of their customary forest. The community's knowledge and understanding of the importance of mangrove forests are due to the high level of community dependence on mangrove forests for livelihoods as fishermen (economic function) and the function of mangrove forests to protect settlements (physical and ecological barriers). Through the years, both officials and Jaring Halus community have made efforts to develop certain sites for ecotourism, although they still need a lot of improvements. This is because the development of the Jaring Halus Village area in the future will become a dependable place for thousands of residents around the tourism area. People also try to be independent and sell various processed food ingredients from fish that they produce themselves so that they can become typical souvenirs of Jaring Halus Village for the visitors.

The Langkat District government has increasingly conducted socialization on implementing government regulations through related agencies to protect the mangrove forests and its coastal areas from irresponsible and detrimental to the community, especially in the lack of written regulations. However, such efforts are only in the form of counseling about the benefits if mangrove forests exist and consequences if they do not exist. This seems very insufficient considering the relatively limited number of extension workers and not equipped with adequate tools. The officials may also understand the community about the utilization of mangroves and efforts to replant mangrove forests. From the interview results, it was known that there was awareness from the community to replant degraded mangrove forests by taking mangrove fruits/seeds and seeding them independently and then planting them again in the village mangrove forest. The people of Jaring Halus Village sell mangrove seedlings from their own nurseries (seedlings from village forests) at a price of IDR 200-300 per polybag from Langkat District to Aceh. Even though the selling price is low, the community makes this an alternative to income because the seeds are easy to obtain and cultivate.

Collaborative efforts between the community and the government are required to use and manage mangroves and involve the community in planning and implementing mangrove management. Law No. 23/1997 explains that one of the tasks of the government is to form a partnership with the community and the business actors in environmental management. Support from the government as the formal institution to lead a partnership is very necessary, considering that the government has the authority to determine the policies that are transparent and impartial. Even though the actors involved in the partnership are equal, the support from the government can serve as an impetus for the formation of partnerships.
In conclusion, to achieve sustainable mangrove management in the coastal area of Jaring Halus Village, it is better to provide awareness and knowledge to coastal area stakeholders about the importance of mangrove ecosystem management by increasing mangrove education options by conducting seminars, dialogues, providing education and open training to the Jaring Halus community regarding the sustainable framework of mangrove forest utilization.

\section{REFERENCES}

Agoramoorthy G, Chen F, Venkatesalu V, Kuo D, Shea P, 2008. Evaluation of antioxidant polyphenols from selected mangrove plants of India. Asian J Chem 20 (2): 1311-1322.

Aida N, Zuska F. 2017. Kearifan lokal dalam pengelolaan wilayah pesisir di Desa Jaring Halus. Jurnal Antropologi Sumatera 15(1): 270-279. [Indonesian]

Aksornkoae S, Kato S, 2011 Mangroves for the people and environmental conservation in Asia. Bull Soc Sea Water Sci 65 (1): 3-9.

Alimbon JA, Manseguiao MRS. 2021. Community knowledge and utilization of mangroves in Panabo Mangrove Park, Panabo City, Davao del Norte, Philippines. Intl J Bonorowo Wetl 11 (2): 51-57. DOI: 10.13057/bonorowo/w110201.

Ardli ER, Yani E, Widyastuti A. 2011. Density and spatial distribution of Derris trifoliata and Acanthus ilicifolius as a biomonitoring agent of mangrove damages at the Segara Anakan lagoon (Cilacap, Indonesia). $2^{\text {nd }}$ International Workshop for Conservation Genetics of Mangroves.

Badan Pusat Statistik (BPS) Kabupaten Langkat. 2017. Langkat dalam Angka 2015. Langkat, Sumatra Utara, Indonesia. [Indonesian]

Badan Pusat Statistik (BPS) Kabupaten Langkat. 2018. Langkat dalam Angka 2015. Langkat, Sumatra Utara, Indonesia. [Indonesian]

Balai Besar Konservasi dan Sumberdaya Alam (BBKSDA) Sumatera Utara. 2009. Suaka Margasatwa Karang Gading dan Langkat Timur Laut. Medan, Indonesia. [Indonesian]

Balai Besar Konservasi Sumberdaya Alam Sumatera Utara (BBKSDASU). 2009. Rencana pengelolaan Suaka Margasatwa Karang Gading dan Langkat Timur Laut: periode 2010-2029. [Unpublished] [Indonesian]

Balai Konservasi Sumberdaya Alam (BKSDA) Sumatera Utara. 2019. Kawasan Ekosistem Esensial Jaring Halus. Langkat, Sumatra Utara, Indonesia. [Indonesian]

Bengen DG. 2000. Ekosistem dan sumberdaya pesisir dan laut serta pengelolaan secara terpadu dan berkelanjutan. Prosiding Pelatihan Pengelolaan Wilayah Pesisir Terpadu. Institut Pertanian Bogor, Bogor, Indonesia. [Indonesian]

Bengen DG. 2001. Pedoman Teknis Pengenalan dan Pengelolaan Ekosistem Mangrove. Institut Pertanian Bogor, Bogor, Indonesia. [Indonesian]

Bengen GD. 2004. Sinopsis Ekosistem dan Sumberdaya Alam Pesisir dan Laut serta Prinsip Pengelolaannya. Institut Pertanian Bogor, Bogor, Indonesia. [Indonesian]

Djufri. 2015. Leuser Ecosystem of Aceh Province as a natural laboratory for the study of biodiversity to find the raw materials of drugs. Pros Sem Nas Masy Biodiv Indon 1 (7): 1543-1552. DOI: $10.13057 / \mathrm{psnmbi} / \mathrm{m} 010701$.

Giri C, Long J, Abbas S, Murali RM, Qamer FM, Pengra B, Thau D. 2015. Distribution and dynamics of mangrove forests of South Asia. J Environ Manag 148: 101-111. DOI: 10.1016/j.jenvman.2014.01.020.

Giri C, Ochieng E, Tieszen LL, Zhu Z, Singh A, Loveland T, Masek J, Duke N. 2011. Status and distribution of mangrove forests of the world using earth. Global Ecol Biogeogr 20 (1): 154-159. DOI: 10.1111/j.1466-8238.2010.00584.x.

Hutchison J, Manica A, Swetnam R, Balmford A, Spalding M. 2014. Predicting global patterns in mangrove forest biomass. Conserv Lett 7 (3): 233-240. DOI: 10.1111/conl.12060.

Janmaimool P. 2016. The establishment of a community-based mangrove forest management plan: lessons learned from mangrove forest conservation in the Nernkhor Sub-district, Rayong Province Thailand. Appl Environ Res 38 (3): 59-75. DOI: 10.35762/AER.2016.38.3.6. 
Joshi HG, Ghose M. 2014. Community structure, species diversity, and aboveground biomass of the Sundarbans mangrove swamps. Trop Ecol 55 (3): 283-303.

Karlina E, Kusmana C, Marimin, Bismark M. 2016. Analysis of sustainability of mangrove protection forest management in Batu Ampar, Kubu Raya District, West Kalimantan Province. Jurnal Analisis Kebijakan Kehutanan 13 (3): 201-219. DOI: 10.20886/jakk.2016.13.3.201-219. [Indonesian]

Kathiresan K, Bingham BL. 2001. Biology of mangrove and mangrove ecosystems. Adv Mar Biol 40: 81-251. DOI: 10.1016/S00652881(01)40003-4.

Kavanagh P, Pitcher TJ. 2004. Implementing microsoft excel software for Rapfish: A technique for the rapid appraisal of fisheries status. University of British Columbia, Canada.

Kusmana C, Onrizal, Sudarmadji. 2003. Jenis-jenis pohon mangrove di Teluk Bintuni, Papua. Institut Pertanian Bogor, Bogor, Indonesia. [Indonesian]

Kusmana C. 2014. Distribution and current status of mangrove forests in Indonesia. In: Hanum FI, Latiff A, Hakeem KR, Ozturk M (eds) Mangrove ecosystem of Asia: status, challenges and management strategies. Springer Science and Business Media. DOI: 10.1007/978 1-4614-8582-7_3.

Machado IC, Fagundes L, Henriques MB. 2015. Multidimensional assessment of sustainability extractivism of mangrove oyste Crassostrea spp. in the estuary of Cananéia, São Paulo, Brazil. Braz J Biol 75: 670-678. DOI: 10.1590/1519-6984.20713.

Marbawa IKC, Astarini IA, Mahardika IG. 2014. Analisis vegetasi mangrove untuk strategi pengelolaan ekosistem berkelanjutan $\mathrm{d}$ Taman Nasional Bali Barat. Ecotrophic: Jurnal Ilmu Lingkungan 8 (1): 24-38. [Indonesian]

Muhtadi A. Rudi HS, Rusdi L, Zulham AH. 2016. Ecological status of mangrove of Sembilan Island, Langkat District, North Sumatra Province. Depik Jurnal Ilmu-Ilmu Perairan, Pesisir dan Perikanan 5 (3): 151-163. DOI: 10.13170/depik.5.3.5656. [Indonesian]

Nfotabong-Atheull A, Din N, Koum LGE, Satyanarayana B, Koedam N, Dahdouh-Guebas F. 2011. Assessing forest products usage and local residents' perception of environmental changes in peri-urban and rura mangroves of Cameroon, Central Africa. J Ethnobiol Ethnomed 7 (1): 1-13. DOI: 10.1186/1746-4269-7-41.

Pendleton L, Donato DC, Murray BC, Crooks S, Aaron JW, Sifleet S, Craft C, Fourqurean JW, Kauffman JB, Marba N, Megonigal P, Pidgeon E, Herr D, Gordon D, Baldera A. 2012. Estimating global "blue carbon" emissions from conversion and degradation of vegetated coastal ecosystems. PLoS ONE 7: e43542. DOI: 10.1371/journal.pone.0043542.

Pitcher TJ, Preikshot D. 2001. RAPFISH: A rapid appraisal technique to evaluate the sustainability status of fisheries. Fish Res 49 (3): 255 270. DOI: 10.1016/S0165-7836(00)00205-8.
Polidoro BA, Carpenter KE, Collins L, Duke NC, Ellison AM, Ellison JC, Farnsworth EJ, Fernando ES, Kathiresan K, Koedam NE, Livingstone SR, Miyagi T, Moore GE, Nam VN, Ong JE, Primavera JH, Salmo III SG, Sanciango JC, Sukardjo S, Wang Y, Yong JWH. 2010. The loss of species: mangrove extinction risk and geographic areas of global concern. PLoS ONE. 5 (4): e10095. DOI: 10.1371/journal.pone.0010095.

Prasetyo DE, Ferbrian KA, Firman Z, Hani SP, Achmad S, Anisa B, Edy S. 2014. Kajian sosio-ekologis kawasan mangrove di Pesisir Pantai Kecamatan Biduk-Biduk, Kalimantan Timur. Omni-Akuatika 10 (1): 1-9. [Indonesian]

Richards DR, Friess DA. 2016. Rates and drivers of mangrove deforestation in Southeast Asia, 2000-2012. Proc Natl Acad Sci USA 113 (2): 344-349. DOI: 10.1073/pnas.1510272113.

Rugayah S. 2007. Mangrove plant diversity in Sepanjang Island, East Java. Biodiversitas 8 (2): 130-134. DOI: 10.13057/biodiv/d080211.

Setiawan H, Rini P, Garsetiasih R. 2017. Perception and attitude of community towards mangrove ecosystem conservation at Tanakeke Island-South Sulawesi. Jurnal Penelitian Sosial dan Ekonomi Kehutanan 14: 57-70. DOI: 10.20886/jpsek.2017.14.1.57-70. [Indonesian]

Snedaker SC. 1984. The Mangroves of Asia and Oceania: Status and Research Planning. University of Malaya and UNESCO, Kuala Lumpur, Malaysia.

Spalding MD, Kainuma M, Collins L. 2010. World Atlas of Mangroves. Earthscan Ltd, Washington DC. DOI: 10.4324/9781849776608.

Sudtongkong C, Webb EL. 2008. Outcomes of state vs. community based mangrove management in southern Thailand. Ecol Soc 13 (2): 27. DOI: 10.5751/ES-02531-130227.

Thomas N, Lucas R, Bunting P, Hardy A, Rosenqvist A, Simard M. 2017. Distribution and drivers of global mangrove forest change, 19962010. PLoS ONE 12: e0179302. DOI: 10.1371/journal.pone.0179302.

Valiela I, Bowen JL, York JK. 2001. Mangrove forests: One of the world's threatened major tropical environments. BioScience 51 (10): 807-815. DOI: 10.1641/0006-3568(2001)051[0807:MFOOTW]2.0.CO;2.

Van Lavieren H, Spalding M, Alongi D, Kainuma M, Clüsener-Godt M. and Adeel Z. 2012. Securing the future of mangroves. A Policy Brief. UNU-INWEH, UNESCO-MAB with ISME, ITTO, FAO, UNEPWCMC and TNC.

Wouthuyzen S, Ahmad F. 2018. Mangrove mapping of the Lease Islands, Maluku Province using multi-temporal and multi-sensor of Landsat satellite images. Oseanologi dan Limnologi di Indonesia 3 (1): 19-37. DOI: 10.14203/oldi.2018.v3i1.134. [Indonesian]

Zhang CG, Leung KK, Wong YS, Tam NFY. 2007. Germination, growth and physiological responses of mangrove (Bruguiera gymnorrhiza) to lubricating oil pollution. Environ Exp Bot 60 (1): 127-133. DOI: 10.1016/j.envexpbot.2006.09.002. 